\title{
From EU-phoria to EU-phobia? Changing Turkish Narratives in EU-Turkey Relations
}

\author{
Gözde Yılmaz \\ Atılım University \\ Kızılcaşar Mah. İncek, \\ Ankara 06830, Turkey \\ E-mail: gozde.yilmaz@atilim.edu.tr
}

\begin{abstract}
Since the 1999 launch of EU candidate country status, EU-Turkey relations have reached a new level of closer engagement. Across time, the relations demonstrate different levels of engagement and, accordingly, different narratives. Regarding the Turkish narratives of the EU, the EU is framed across time as follows: EU as a democratic anchor; EU as a disappointment; EU as an untrustworthy entity; $E U$ as an enemy. As seen, Turkish narratives demonstrate a trend from EU-phoria to EU-phobia. In the end, it is important that EUTurkey relations and Turkish narratives on the EU are not immune to domestic developments, especially those shaped by populist politics in the last two decades.
\end{abstract}

Keywords: democratic anchor, EU-phobia, EU-phoria, European Union, Turkey

\section{Introduction}

EU-Turkey relations have always been fluctuating and have endured many crises since the beginning of the relations for more than half a century ago. However, the recent estrangement in the relations suggests a certain rupture of Turkey from the EU and the current phase in the relations shows a process of enemization of Europe by the Turkish authorities in line with their populist discourse. In the end, EU-Turkey relations cannot be immune to domestic developments, especially those shaped by populist politics in the last two decades.

In today's world, populism is often referred to increasingly within European and 
North and Latin American contexts and rarely beyond those. However, there are various cases demonstrating a rise in populism throughout the world rather than focusing on specific regions. In the last decade, Turkish populist politics has strongly entered the scene, especially in the second term of the Justice and Development Party (Adalet ve Kalkınma Partisi, or AKP) in the country.

The AKP's narratives on the EU have radically changed over time from the EU as a democratic anchor to the EU as a disappointment, the EU as an unreliable entity and, finally, to the EU as an enemy. While EU-phoria regarding the EU accession predominated in the golden years of EU-Turkey relations until 2005, Turkey became very disappointed in the privileged partnership debate among EU Member States in 2005 and, in the time that followed, the EU was framed first as a disappointment and an unreliable entity. By the 2013 Gezi Park protests in Turkey, EU-Turkey relations had become tense due to criticisms of the EU and dismissal of such criticisms by the Turkish authorities. Since that, the EU has been enemized by the Turkish government in various contexts.

This article focuses on the Turkish narratives of the EU across time since the launch of its candidate country status in 1999. It explores whether there is a radical transformation in the discursive side, and why. The article argues that different narratives emerge about the EU in line with the governmental interests of the AKP. Ultimately, a populist rhetoric has increasingly dominated the EU narratives and the EU has recently been enemized by the ruling party. All in all, a radical transformation in the Turkish rhetoric of the EU reflects the nature of the EU-Turkey relations in the last decades.

The article analyses the discursive turn in Turkish discourse over time starting with the first period 1999-2004 of 'EU as a democratic anchor'. Next, it focuses on the period 2005-2007, 'EU as a disappointment', and continues by exploring the period 2008-2012 describing 'EU as an unreliable entity'. Following that the article analyses the last period from 2013 onwards - 'EU as an enemy'. Last, it provides concluding remarks.

\section{The discursive turn: from EU-phoria to EU-phobia}

EU-phoria was in the air in 1999, when the EU granted Turkey the candidate country status. The coalition government of the time, despite limited and struggling with reforms, confirmed its support to Turkey's accession process to the EU (Keyman \& Öniş, 2007, p. 41). With the AKP coming to power in 
2002, even further enthusiasm for the accession process, this time with strong compliance with the EU's norms and rules, was dominant among both the government members and the general public (Eurobarometer, 2002; 2003; 2004; Yilmaz, 2016). In addition to the compliance, AKP's references to the EU were quite positive with a high degree of consistency in their support to the accession process to the EU.

The abovementioned picture transformed into a different one with the privileged partnership debate among EU Member States on Turkey's potential membership in the EU in 2005. Over time, regardless of the accession process, the EUTurkey relations reached a level of estrangement and even split (Yilmaz, 2016). Such transformation in the relations is reflected in the discourse of the AKP's successive single-party government's representatives.

\subsection{EU as a democratic anchor: 1999-2004}

The period of 1999-2004 marks the golden years in EU-Turkey relations (Öniş, 2008). The commitment of the EU to Turkey's possible membership was strengthened by the launch of EU candidate country status for Turkey in 1999 and led to a consensus in the domestic arena for launching reforms in order to reach the ultimate aim-EU membership (Eylemer \& Taş, 2007, p. 572; Keyman \& Öniş, 2008, p. 40; Oğuşgil, 2016, p. 71). The process accelerated, especially with the AKP coming to power. Declaring the EU membership as a national goal for Turkey (e.g., AKP Political Group, 2002; 2003), Prime Minister at the time Erdoğan emphasized the consensus on that with the following words: "in Turkey, there is a broad consensus among the government, opposition party, public agencies, civil society organizations, media and intelligentsia on the issue of the EU" (Erdoğan, 2004).

In this period, both the EU and Turkey were quite positive regarding Turkey's accession process. On the one hand, the EU was strictly referring to furthering Turkish accession process if the Copenhagen criteria was fulfilled, therefore, without any negative considerations other than the criteria emphasized as follows: "If the European Council in December 2004, on the basis of a report and a recommendation from the Commission, decides that Turkey fulfills the Copenhagen political criteria, the European Union will open accession negotiations with Turkey without delay" (Council of the European Union, $15917 / 02$, p. 5). On the other hand, in line with the EU statements, the Turkish discursive framework was also one with positive references to the EU including Turkey's commitment to the EU accession process and optimism about furthering the process with the possible EU decision to launch accession negotiations: "We 
are optimistic but also realistic about the launch of accession negotiations with the EU in December 2004." (AKP Political Group, 2004)

In the end, Turkey was transformed by the reforms launched in this golden era with increasing references to the EU accession process. Therefore, the EU constituted a democratic anchor and the EU membership a national goal for Turkey in this period. Notably, even in the case of potential problems in the relations, Turkish government declared its decisiveness to continue reforms. To illustrate this, if the EU decision was negative for the launching accession negotiations with Turkey, Prime Minister Erdoğan stressed, with the following words, that reforms would continue: "In December 2004, the Copenhagen criteria will give the result that we want or not. What happens if it will not? We will call them Ankara criteria and continue on the course." (AKP Political Group, 2004)

\subsection{EU as a disappointment: 2005-2007}

After the EU decided to launch accession negotiations in 2005, debates flourished among EU Member States following the decision. Germany, France, and Austria - who were among the EU Member States who opposed the enlargement to include Turkey—proposed a 'privileged partnership' rather than full membership in order to keep accession negotiations open-ended. This made alternative outcomes of the accession process possible instead of an EU membership (Öniş, 2010, p. 364; Schimmelfennig, 2009, p. 418). The debate among the EU Member States focused on the absorption capacity of the Union, in which the ability of the EU to absorb Turkey with its size, population, and culture was discussed (Öniş, 2010, p. 365). In the end, "Other 'non-Copenhagen criteria' reasons started to be aired openly, summed up in the heightened concern about the EU's 'absorption capacity" (Narbone \& Tocci, 2007, p. 238). It is vital to note that absorption capacity had previously been considered as part of the Copenhagen criteria; however, it had rarely been applied until the Turkish accession process (Kirişçi, 2007, p. 8).

Besides, in the post-2004 period, the most important issue was the frozen Cyprus conflict and its repercussions for Turkey's accession process (International Crisis Group, 2007, p. 17). The Cyprus problem in Turkey's accession process captured direct attention with the Turkish government's signature of the Additional Protocol to the Ankara agreement in July 2005, which extended the Customs Union to all new Member States, including the Republic of Cyprus (RoC) (Açıkmeşe \& Aydın, 2007). Tensions between the parties arose when Turkey issued a unilateral declaration stating that its signature did not mean a 
formal recognition of RoC (i.e. recognition of the Greek Cypriot government as the legitimate representative of all Cyprus) (Aybet, 2006, p. 532). In response, the EU declared in September 2005 that recognition of all Member States is an integral part of accession negotiations (Ulusoy, 2009, p. 401). Eventually, Ankara refused to implement the Additional Protocol unless the EU lifted the isolation of the Northern Turkish part of Cyprus, which was undertaken by the EU in 2004 (Müftüler-Baç, 2008, p. 208). In turn, the refusal of Turkey to implement the Additional Protocol, fully comprising all new Member States including RoC, led to a freeze in many chapters within the accession negotiations (Oğuşgil, 20016, p. 73; Schimmelfennig, 2009, p. 428).

The decision to put the related negotiation chapters on hold was translated in the domestic arena of Turkey as unfair treatment of the country by the EU who employed double standards on the RoC and Turkey. The source of this was the idea that the Union accepted the divided island of RoC as a Member State without conditioning resolution of the conflict, while demanding a resolution of Turkey for its accession (Saatçioğlu, 2009). This created a sense of Europe's hypocrisy and unfair treatment on Turkey-related issues among Turkish elites and the general public (Öniş, 2009, p. 26).

The debates on the privileged partnership and the EU's demand for the recognition of the RoC and the implementation of the Additional Protocol by Turkey were perceived in the domestic arena as substantial discrimination among candidate states. In turn, public support for EU membership started to fall by 2005 (Eurobarometer, 2005a, b; 2006; 2007). Such fall highlights a loss of public enthusiasm for Turkey's accession process and a growing public disenchantment with the EU.

While the public arena lost its enthusiasm in the EU accession process in this period, the AKP leaders put a heavy emphasis on Turkey's unconditional membership in the EU in response to the alternative prospects offered for Turkey by some circles in the EU (e.g., privileged membership discussions for Turkey among EU Member States, see AKP Political Group, 2005a). Moreover, speeches of AKP leaders increasingly reflected discontent with the EU's references to the criteria other than the Copenhagen criteria, which started to be emphasized more by 2005 (AKP Political Group, 2005b).

Most importantly, the Cyprus issue was translated by the AKP government as unfair treatment on the part of the EU towards Turkey as the resolution of the issue had become a precondition for Turkey's accession (AKP Political Group, 2005b). Because the AKP government had adopted a policy separating the 
EU accession process from the Cyprus issue, the EU's agenda regarding the membership of the RoC created a reactive attitude by the AKP towards the EU (Erdoğan, 2006). While keeping the Cyprus issue separate from the accession process, the government emphasized in many speeches the unfair treatment by the EU concerning the Cyprus problem (e.g., AKP Political Group, 2005b).

All in all, this period signifies a break from the previous discourse of the Turkish government, as the EU was framed as a disappointment due to the developments regarding Turkey's possible EU membership. Although the government declared its continuing commitment to the reforms and EU accession process, it also suggested an unconditional membership prospect for Turkey (AKP Political Group, 2005a; 2005c). In the end, hopes for Turkey's membership in the EU were damaged because of the privileged membership debates and repercussions of the Cyprus issue, despite the launch of accession negotiations. This was even furthered in the following years.

\subsection{EU as an unreliable entity: 2008-2012}

Similarly to the beginning of the previous period, the significant turn in the AKP's discourse on the EU and EU accession process continued in this period. Although the AKP leaders stated, in some instances, the commitment of the AKP government to the accession process (e.g., AKP Political Group, 2009a; 2010; Erdoğan, 2008), the focus of the party shifted away from accession and remained superficial. Moreover, by 2008, the AKP leaders increasingly stressed the need for the EU to keep its commitments-referring to the privileged partnership debates and the Cyprus issue (e.g., AKP Political Group, 2008a; 2009b; Erdoğan, 2009). This reflects a loss of trust in the EU delivering its commitments or rewards.

In addition to the government's loss of trust on the EU regarding the possible EU membership, Turkish public support for the EU membership also decreased to very low levels compared to previous years, signaling that Turkey's accession process to the EU had become a low denominator in domestic politics (Eurobarometer, 2008; 2010; 2013; 2015; 2016). Ultimately, the EU had become an unreliable entity for both Turkish government and the public.

Most notably, the change in the AKP discourse reveals a decreasing focus of the AKP government on the EU accession process acknowledging unfairness of the EU and increasing emphasis on reforms as a domestic choice in response to domestic problems. Therefore, the AKP leaders explicitly shifted emphasis from the EU membership to the domestic utility of reforms and the necessity of 
EU standards for the benefit of the country, irrespective of accession illustrated as follows:

We maintain our path by replacing the Maastricht Criteria with the
Istanbul Criteria and the Copenhagen Criteria with Ankara Criteria
$[\ldots]$ Despite all the obstacles and unfair treatment [...] we are
committed to the accession process to the EU. (AKP Political Group,
2009c)

To sum up, during this period, the AKP adopted more qualified support for the EU accession process that is reflected in its discourse (Yilmaz, 2014, pp. 249, 251). Therefore, while the AKP showed decreasing reliance on a pro-EU approach, it continued to refer to EU standards, although not for membership but for the benefit of Turkish citizens: "Our aim is to carry Turkey to the EU standards and our democracy to an advanced level" (AKP Political Group, 2008b).

\subsection{EU as an enemy: from 2013 onwards}

The EU turned into an enemy in the Turkish domestic arena starting with the 2013 Gezi Park protests. The protests constituted a turning point in the EUTurkey relations and, accordingly, a discursive turn as well. When the AKP government faced criticism from the European Parliament (EP) with a resolution on Taksim Gezi Park protests in Turkey, expressing concerns over the response of the police and government to the protestors, and criticizing the government for its policies during the demonstrations (European Parliament Resolution B70305/2013), Prime Minister Erdoğan responded to the criticism by stating that he did not recognize the EP's decision (Radikal, 2013a). Such a statement reflects an estrangement of Turkey from the EU in the recent years as well as a transition from the EU as a frame of an unreliable entity to the EU as a frame of an enemy. The changing course of AKP's foreign policy toward the East, particularly the Middle East, in recent years also demonstrates the estrangement (Oğuzlu, 2012, p. 236). Various statements by AKP representatives confirmed this changing balance, such as Erdoğan's statement in November 2013 expressing Turkey's wish for a free trade agreement with Eurasian states and calling the concerned states to accept Turkey as a member of the Shanghai Cooperation Organization (Radikal, 2013b).

Despite the estrangement, there were a few positive developments, related to the interest-based cooperation due to new challenges for both. In 2013, the blockage of France on one chapter of negotiations was removed and the chapter was opened and, due to refugee crises, EU-Turkey Readmission Agreement was 
signed with an EU's promise regarding visa liberalization for Turkish citizens. In 2015, the EU-Turkey Joint Action Plan was launched again to deal with the refugee crises.

Although the winds changed to the positive after the refugee deal, the upcoming years demonstrated a phase of deep mutual distrust which was also reflected in the discourse of the AKP government. Therefore, the relations did not only remain at the level of estrangement but also worsened and demonstrated high degrees of enemization of the EU and Europe by the Turkish authorities.

The previous flow of the EU as a disappointment and an unreliable entity in the AKP discourse continued to be dominant in this period, yet with an additional 'EU as an enemy' frame. For instance, regarding the accession negotiations, Erdoğan stated in 2016: "forcing to end the negotiations for a full membership is hypocrisy and political immorality" (Deutsche Welle, 2016a). Additionally, again in 2016, in response to the EP's decision advising to freeze accession negotiations with Turkey, Erdoğan even further sharpened its accusations and swiftly threatened the EU by opening Turkish borders referring to the readmission agreement (Deutsche Welle, 2016b). Year by year, Turkish government's attitude specifically towards the EU Member States and the EU in general worsened and the EU has been perceived and portrayed more as an enemy rather than a partner.

The year 2017 marks the tipping point of the abovementioned enemization-based discourse. Sparks were flying when the government of Netherlands refused to let Turkish foreign minister campaign for a Turkish referendum regarding the presidential system and expel another Turkish minister from its territories. This quickly turned into a diplomatic dispute and expanded to Germany, which had previously warned Turkish politicians who aimed to campaign in Germany on security issues. In response to the Dutch government's negative reply, Erdoğan called them "fascists" and "Nazi remnants", as he had also called Germans just a few days before (Rubin, 2017). This diplomatic crisis was based on the estrangement and the enemization strategy as clearly declared by Erdoğan, who called on the Turkish people living in Germany not to vote for Christian Democrats, SPD and Greens at the German elections and added that "they are all enemies of Turkey" (Yeniçağ Gazetesi, 2017).

To conclude, especially starting in 2013, the EU-Turkey relations evolved into those reflecting estrangement and mutual distrust. Yet, this has been a general trend valid for both Europe and the United States, which constitutes the West for Turkey. The discursive turn towards enemization reflects this as well. To illustrate, Erdoğan's words on the diplomatic crisis with Netherlands clearly 
reflect this as follows: "They show us the real face of the West. We do not want to see that. The Chancellor of Germany is also on the side of Netherlands. Shame on you [...]." (Al Jazeera Türk, 2017)

\section{Concluding remarks: from EU-phoria to EU-phobia}

The EU-Turkey relations mostly had a fluctuating trend, as did the narratives of both sides. Yet, when reflecting the nature of the relations, a dramatic change in Turkish narratives about the EU has been seen and is demonstrated particularly strikingly with the recent statements of Turkish authorities reflecting a deep distrust to the EU.

The EU is portrayed by the Turkish authorities in four different discursive frames in four different time periods: EU as a democratic anchor in 19992004, EU as a disappointment in 2005-2007, EU as an unreliable entity in 2008-2012, and EU as an enemy by 2013. While in the first period the EU was framed as a democratic and transforming institution, the disappointment in the developments of the relations, such as the privileged partnership proposal of some members to Turkey, was reflected in 2005-2007. In 2008-2012, the EU was further framed as unfair and unreliable due to the loss of trust in the EU regarding the membership prospective. By 2013, the EU has been enemized by the ruling party in line with their increasing populist rhetoric. These frames are all in line with the relations of the time and government interests reflecting the same trend from EU-phoria to EU-phobia, in other words, from very much enthusiasm to deep distrust.

In the end, deep fluctuations and a radical transformation are seen in the EU-Turkey relations and in the Turkish narratives related to the EU. Most importantly, the changing narratives, while showing the nature of the relations, reflect domestic politics, which has been determined long before by the populist politics and policies of the AKP relying on sharp enemization strategy and other strategies of populism. Therefore, it is not a surprise to lately see the relations of the EU and Turkey being based on enemy-based narratives due to the needs of domestic politics in Turkey.

The EU-Turkey relations beg for further attention and revival. For that purpose both the EU and the AKP government of Turkey should focus on the positive gains from the relations. While the EU needs to pay attention to its fair and credible attitude towards Turkey's membership process, the Turkish government 
should abandon its recent populist acts and discourses enemizing the EU. Through this, the relations may further be strengthened and there could be a discursive turn on the Turkish side towards the EU.

Dr. Gözde Yılmaz is an associate professor at the Atılım University, Turkey. She completed her PhD in Berlin Graduate School for Transnational Studies (BTS), Free University Berlin. She has a BA degree in international relations from the Hacettepe University and an MA degree in international studies (European integration) from the University of Birmingham. In her PhD project, she studied external Europeanization theories and Turkey's minority rights policy and put forward an interactive theoretical framework for external Europeanization. Her further research interests are European integration, Europeanization theories, external Europeanization, EU enlargement policy, European Neighbourhood Policy, Europeanization of Turkey, EU-Turkey relations, EU-Ukraine relations and populism.

\section{References}

Açıkmeșe, S. A. \& Aydın, M. (2007), 'Europeanization through EU conditionality: understanding the new era in Turkish foreign policy,' Journal of Balkan and Near Eastern Studies, vol. 9, no. 3, pp. 263-274.

AKP Political Group (2002), Prime Minister and Chairman of the AKP Recep Tayyip Erdoğan's Speech to his Political Group, February 13, 2002.

AKP Political Group (2003), Prime Minister and Chairman of the AKP Recep Tayyip Erdoğan's Speech to his Political Group, November 18, 2003.

AKP Political Group (2004), Prime Minister and Chairman of the AKP Recep Tayyip Erdoğan's Speech to his Political Group, May 4, 2004.

AKP Political Group (2005a), Prime Minister and Chairman of the AKP Recep Tayyip Erdoğan's Speech to his Political Group, February 23, 2005, Ankara.

AKP Political Group (2005b), Prime Minister and Chairman of the AKP Recep Tayyip Erdoğan's Speech to his Political Group, April 27, 2005, Ankara.

AKP Political Group (2005c), Prime Minister and Chairman of the AKP Recep Tayyip Erdoğan's Speech to his Political Group, May 24, 2005, Ankara.

AKP Political Group (2008a), Prime Minister and Chairman of the AKP Recep Tayyip Erdoğan's Speech to his Political Group, February 12, 2008, Ankara.

AKP Political Group (2008b), Prime Minister and Chairman of the AKP Recep Tayyip Erdoğan's Speech to his Political Group, November 11, 2008, Ankara.

AKP Political Group (2009a), Prime Minister and Chairman of the AKP Recep Tayyip Erdoğan's Speech to his Political Group, February 10, 2009, Ankara. 
AKP Political Group (2009b), Prime Minister and Chairman of the AKP Recep Tayyip Erdoğan's Speech to his Political Group, June 9, 2009, Ankara.

AKP Political Group (2009c), Prime Minister and Chairman of the AKP Recep Tayyip Erdoğan's Speech to his Political Group, November 3, 2009, Ankara.

AKP Political Group (2010), Prime Minister and Chairman of the AKP Recep Tayyip Erdoğan's Speech to his Political Group, March 2, 2010, Ankara.

Al Jazeera Türk (2017), 'Erdoğan'dan Merkel'e Sana Yazıklar Olsun,' 13 March.

Aybet, G. (2006), 'Turkey and the EU after the first year of negotiations: reconciling internal and external policy challenges,' Security Dialogue, vol. 37, no. 4, pp. 529-549.

Council of the European Union (2003), Copenhagen European Council, Presidency Conclusions, December 12 and 13, 15917/02, POLGEN 84 (2002), Brussels, 29.01.2003.

Deutsche Welle (2016a), 'Erdoğan'dan AB Müzakereleriyle ilgili Açıklama,' 6 September.

Deutsche Welle (2016b), 'Erdoğan AB'yi tehdit etti: Sınırları açarız,' 25 November.

Erdoğan (2004), Prime Minister Erdoğan's Address to the Nation, December, Ankara.

Erdoğan (2006), Prime Minister Erdoğan's Address to the Nation, January, Ankara.

Erdoğan (2008), Prime Minister Erdoğan's Address to the Nation, June, Ankara.

Erdoğan (2009), Prime Minister Erdoğan's Address to the Nation, June, Ankara.

Eurobarometer (2003), Candidate Countries Eurobarometer-CCEB.

Eurobarometer (2004), Candidate Countries Eurobarometer-CCEB.

Eurobarometer (2005a), Candidate Countries Eurobarometer-CCEB.

Eurobarometer (2005b), Standard Eurobarometer 63: National Report Turkey.

Eurobarometer (2006), Standard Eurobarometer 65: National Report Turkey.

Eurobarometer (2007), Standard Eurobarometer 67: National Report Turkey.

Eurobarometer (2008), Standard Eurobarometer 69: National Report Turkey.

Eurobarometer (2011), Standard Eurobarometer 74: National Report Turkey.

Eurobarometer (2013), Standard Eurobarometer 79: National Report Turkey.

Eurobarometer (2015), Standard Eurobarometer 84: National Report Turkey.

Eurobarometer (2016), Standard Eurobarometer 86: National Report Turkey.

European Parliament Resolution on the Situation in Turkey, B7-0305/2013, Brussels, 11.06.2013.

Eylemer, S. \& Ilkay, T. (2007), 'Pro-EU and Eurosceptic Circles in Turkey,' Journal of Communist Studies and Transition Politics, vol. 23, no. 4, pp. 561-577. https://doi.org/10.1080/13523270701674657

International Crisis Group (2007), Turkey and Europe: The Way Ahead, Europe Report no. 184,17 August.

Keyman, F. \& Öniş, Z. (2007), Turkish Politics in a Changing World: Global Dynamics and Domestic Transformations, Istanbul: Istanbul Bilgi University Press. 
Kirişçi, K. (2007), 'The limits of conditionality and Europeanization: Turkey’s dilemmas in adopting the EU acquis on asylum,' Paper presented at the 10th EUSA Biennial International Conference, May 17-19, 2007, Montreal.

Müftüler-Baç, M. (2008), 'Turkey's accession to the European Union: the impact of EU's internal dynamics,' International Studies Perspectives, vol. 9, no. 2, pp. 201-219.

Narbone, L. \& Tocci, N. (2007), 'Running around in circles? The cyclical relationship between Turkey and the European Union,' Journal of Balkan and Near Eastern Studies, vol. 9, no. 3, pp. 233-245.

Oğuşgil, V. A. (2016), 'The internal security package and its potential impact on the EU-Turkey relations within the scope of fundamental rights and freedoms,' Baltic Journal of European Studies, vol. 6, no. 1, pp. 69-94.

https://doi.org/10.1515/bjes-2016-0004

Oğuzlu, H. T. (2012), 'Turkey and the European Union: Europeanization without membership,' Turkish Studies, vol. 13, no. 2, pp. 229-243. https://doi.org/10.108 0/14683849.2012.685256

Öniş, Z. (2008), 'Turkey-EU relations: beyond the current stalemate,' Insight Turkey, vol. 10 , no. 4 , pp. $35-50$.

Öniş, Z. (2009), 'The new wave of foreign policy activism in Turkey drifting away from Europeanization?' in Danish Institute for International Studies Report 5, Copenhagen: Danish Institute for International Studies, pp. 1-39.

Öniş, Z. (2010), Contesting for the "Center": Domestic Politics, Identity Conflicts and the Controversy over EU Membership in Turkey, Istanbul Bilgi University European Institute Working Papers, no. 2, Istanbul: Istanbul Bilgi University Press. Radikal (2013a), 'Erdoğan'dan AP'ye rest: Senin haddine mi?' [Erdoğan's reponse to the EP: How dare you?], 14 June.

Radikal (2013b), 'Gelin Türkiye'yi Şangay Teşkilatına alın' [Let's take Turkey in to the Shanghai Cooperation Organization], 22 November.

Rubin, A. J. (2017), 'Erdoğan calls Dutch 'Nazi remnants' after Turkish Minister is barred,' New York Times, 11 March.

Saatçioğlu, B. (2009), 'How closely does the European Union's membership conditionality reflect the Copenhagen criteria? Insights from Turkey,' Turkish Studies, vol. 10, no. 4, pp. 559-576. https://doi.org/10.1080/14683840903384802

Schimmelfennig, F. (2009), 'Entrapped again: the way to EU membership negotiations with Turkey,' International Politics, vol. 46, no. 4, pp. 413-431. https://doi. org/10.1057/ip.2009.5

Ulusoy, K. (2009), 'Europeanization and political change: a new research agenda for Cyprus studies,' Turkish Studies, vol. 10, no. 3, pp. 393-408. https://doi. org/10.1080/14683840903141715 
Yeniçă̆ Gazetesi (2017), ‘Erdoğan ‘Oy Vermeyin’ Dedi Merkel'den Yanıt Geldi,' 31 August.

Yilmaz, G. (2014), 'It is pull-and-push that matters for external Europeanization! Explaining minority policy change in Turkey,' Mediterranean Politics, vol. 19, no. 2, pp. 238-258. https://doi.org/10.1080/13629395.2013.838443

Yilmaz, G. (2016), 'From Europeanisation to de-Europeanisation: the Europeanisation process of Turkey in 1999-2014,' Journal of Contemporary European Studies, vol. 24, no. 1, pp. 86-100. https://doi.org/10.1080/14782804.2015.1038226 